Stevenson, I. L. (1956). J. gen. Microbiol. 15, 372-380

\title{
Antibiotic Activity of Actinomycetes in Soil as Demonstrated by Direct Observation Techniques
}

\author{
By I. L. STEVENSON \\ Bacteriology Division, Science Service, Canadian Department of Agriculture, Ottawa, \\ and Rothamsted Experimental Station, Harpenden, Herts.
}

SUMMARY: Direct observation techniques were used to determine the antibiotic effects of eight actinomycete species on Helminthosporium sativum in soil and in vitro. In actinomycete-inoculated sterilized soils, the inhibition of germination of fungal spores corresponded with the degree of inhibition of the fungus produced by the same actinomycetes in Petri plate culture. The effects of the actinomycetes on the vegetative growth of $\boldsymbol{H}$. sativum in soybean-supplemented soils varied with the individual actinomycetes and, with one exception, were identical with the effects caused by the actinomycete antibiotics in vitro. These hyphal changes in soil included: suspension of further mycelial development; lysis; characteristic morphological effects such as stunting, distortion, excessive branching and the formation of hyphal protuberances. Lysis of the fungal hyphae only occurred in the presence of soil and was shown to be due to the combined effect of the antibiotic and some unidentified soil factor. Evidence was also obtained which demonstrated the ability of the actinomycetes to produce antibiotics in unsupplemented soils. Additional proof of antibiotic activity in soil was obtained by using the antibiotic actinomycin and strains of Streptomyces antibioticus, the organism responsible for its production. In Petri plate culture, both crystalline actinomycin and the actinomycetes produced a characteristic swelling, distortion and stunting of the vegetative growth of Helminthosporium sativum. When introduced into sterile soils, identical morphological changes were evidenced by the fungus in the presence of either the pure antibiotic or the actinomycetes.

Although the ecological significance of antibiotics in soil has often been questioned because of the failure to demonstrate the presence of these substances, the possibility remains that antibiotics are present in amounts too small to be detected, but in sufficient concentration to exert localized inhibitory effects. In the past, the production and accumulation of antibiotics in soil has generally been assessed on the basis of extraction techniques (Gottlieb \& Siminoff, 1952; Grossbard, 1952; Gregory, Allen, Riker, Peterson, 1952) and the frequent failure to detect antibiotics may well be due to the inadequacy of these methods (Stevenson, 1956).

Mitchell, Hooton \& Clark (1941) were among the first to suggest that direct observation of the growth antagonistic processes occurring in soil would aid in the understanding of the mechanisms of biological control. By using a RossiCholodny slide technique these workers showed the decomposition of Phymatotrichum omnivorum by successive groups of soil micro-organisms. Blair $(1943,1945)$ described the use of similar techniques in following the growth behaviour of Rhizoctonia solani under various soil conditions. In the study of fungistasis in the Wareham Heath soils, Jefferys \& Hemming (1953) placed 
slabs of agar in intimate contact with soil and examined them for antibiotic effects by removing the slabs and seeding with a test organism. In this way, these workers were able to detect localized areas of inhibition. Legge (1952), and Dobbs \& Hinson (1953) developed techniques in which test fungi were enmeshed in glass fibre tape or between layers of cellulose film before placing in soil. After a suitable exposure period the tapes or films were removed and examined for antibiotic effects. Chinn (1953) devised a practical buried-slide technique for studying the effects of soil conditions on the germination of fungal spores.

Reilly, Schatz \& Waksman (1945) have shown that antibiotic substances may vary greatly in their antifungal effects. An antibiotic may be fungistatic or fungicidal, depending on its concentration. The presence of an antibiotic may also bring about some physiological change or result in the complete lysis and destruction of the fungus. Another phase of antibiosis, namely, the inducement of morphological change in the antagonized organism, has recently received considerable attention. Numerous workers (Christensen \& Davies, 1940; Lachance, 1951; Tveit, 1953; Rombouts, 1953) have demonstrated the effects of antibiotic substances on germination, hyphal development and morphology of fungi. Brian, Curtis \& Hemming (1946) showed that antibiotics can affect the morphological development of fungi in a characteristic and reproducible manner. These workers demonstrated two distinct effects of the antibiotic griseofulvin on the spores and hyphae of Botrytis allii: (i) inhibition of growth only at a stage subsequent to germination of the conidia; (ii) a remarkable increase in branching and distortion of the hyphae.

In this present paper, a direct observation technique has been employed in which the specific effects of a number of actinomycete antibiotics in Helminthosporium sativum have been used in an attempt to establish the presence and activity of these substances in soils.

\section{METHODS}

The actinomycetes. Eight of the ten Streptomyces spp. used in previous studies (Stevenson, 1956) were employed in the present investigation. Two of the organisms, E4 and E63, were identified as strains of $S$. antibioticus and produced the antibiotic actinomycin (Stevenson, 1956). The actinomycetes $\mathbf{A A 3 0}$, AA 53, AA 24, AA 27, XX19 and Y 27 remain unidentified.

Determination of the in vitro effects of the actinomycete antibiotics on spores of Helminthosporium sativum. The actinomycetes were streak inoculated on plates of Conn's asparagine agar and incubated at $26^{\circ}$ for five days. The plates were then flooded up to the actinomycete growth with $2 \mathrm{ml}$. of potato glucose agar (PG agar) on which was spread $0.5 \mathrm{ml}$. of a heavy suspension of $H$. sativum spores. The plates were re-incubated and examined under the microscope after 1, 3- and 7-day intervals. Microscopic examination: by means of a sharp scalpel, a small rectangle of agar was removed at right angles to the actinomycete-streak and placed on a clean microscope slide (Pl. 1, fig. 1). The surface of the agar block was flooded with a dilute solution of aniline blue 
(in lactophenol) for 2-3 min. and then washed off. Development of the fungal spores was determined by examination of the agar block under a microscope.

Determination of the in vitro effects of the actinomycete antibiotics on predeveloped hyphae of Helminthosporium sativum. In order to determine the antibiotic effects on $H$. sativum hyphae, a spore suspension was added to plates of PG agar and incubated for $24 \mathrm{hr}$. to produce vegetative growth of c. 200-500 $\mu$. long. Actinomycete plates were prepared in the manner described above. Square agar blocks were removed from the actinomycete plates (from areas known to contain the actinomycete antibiotic) and placed in the centre of plates containing $2.4 \mathrm{hr}$. growth of $\boldsymbol{H}$. sativum. These plates were reincubated and examined at 1-, 3- and 7-days by the methods described for spores (Pl. 1, fig. 2).

\section{Buried-slide techniques}

Preparation of spore-slides. A modification of the buried-slide technique of Chinn (1953) was used. Spores of Helminthosporium sativum were suspended in Tween 20 and the suspension was filtered through 200-mesh phosphor bronze wire cloth to remove mycelial fragments. The spore concentration of the suspension was calculated from readings with a Turck haemacytometer, and a final concentration of $2,000,000$ spores $/ \mathrm{ml}$. was obtained by the addition of distilled water. Ten ml. of this suspension was added to $100 \mathrm{ml}$. sterile $1.5 \%$ agar which had previously been melted, cooled and held at $45^{\circ}$.

Ordinary microscope slides, thoroughly cleaned and sterilized, were dipped momentarily into the agar spore suspension, then removed and held horizontally until set. The slides were then inserted vertically about one-quarter of an inch into a shallow layer of sterile soil in the bottom of 3 in. diameter clay pots. After the insertion of the slides, soil alone or actinomycete + soil inoculum was carefully added to the pots. At the end of each specified incubation period ( 1,3 and 7 days), the slides were carefully removed from the pots by the use of a flamed spatula. After removal, the slides were rinsed in water to remove adhering soil particles, and the agar film from one side of the slide was wiped off. The slides were then stained (aniline blue-lactophenol) for 2-3 min. and immediately examined under the microscope. The degree of spore germination $(\%)$ was calculated on the basis of examination of 25 spores on each of two slides.

Preparation of slides with pre-developed hyphae. Spore slides were prepared as described above, but before placing in the soil the slides were incubated for $24 \mathrm{hr}$. in a moist chamber at $26^{\circ}$. Incubation under these conditions prevented the thin agar film from drying out and allowed the germ-tubes to develop to about $200 \mu$. long. The slides were then placed in soil and examined in the usual manner.

Soils and the preparation of actinomycete inocula. The soils and the preparation of actinomycete-soil inocula were described previously (Stevenson, 1956). 


\section{RESULTS}

The in vitro effects of actinomycete antibiotics on germination and development of Helminthosporium sativum

Preliminary experiments were undertaken to determine the antibiotic effects of the eight actinomycetes on spore germination and hyphal development of Helminthosporium sativum. By examining spores and hyphae within the normal inhibition zones of the actinomycetes, it was possible to arrange the antagonists into four groups according to the observed effects on the fungal spores and hyphae. Table 1 summarizes the observations made over a period of 7 days at a point midway through the inhibition zone.

Table 1. Antibiotic effects on spores and pre-developed hyphae of Helminthosporium sativum within the normal inhibition zones of the actinomycetes

\begin{tabular}{|c|c|c|c|}
\hline \multirow{2}{*}{$\begin{array}{l}\text { Actinomycete } \\
\text { strain }\end{array}$} & \multirow{2}{*}{$\begin{array}{l}\text { Width of } \\
\text { zones of } \\
\text { inhibition } \\
(\mathrm{mm} .)\end{array}$} & \multicolumn{2}{|c|}{ Effects of antibiotics on } \\
\hline & & Spores & Pre-developed hyphae \\
\hline $\begin{array}{l}\text { AA 30 } \\
\text { AA 53 }\end{array}$ & $\left.\begin{array}{r}4 \\
10\end{array}\right\}$ & $\begin{array}{l}80 \% \text { germination. Slight } \\
\text { inhibition of further } \\
\text { development }\end{array}$ & $\begin{array}{l}\text { Hyphae remains normal in } \\
\text { appearance. Slight inhibition } \\
\text { of further growth }\end{array}$ \\
\hline $\begin{array}{l}\text { AA } 27 \\
\text { AA } 24\end{array}$ & $\left.\begin{array}{l}20 \\
22\end{array}\right\}$ & $\begin{array}{l}10-20 \% \text { germination. Spores } \\
\text { germinate only to the P.E.I. } \\
\text { stage (Pl. 1, fig. 3). No } \\
\text { further development on } \\
\text { continued incubation }\end{array}$ & $\begin{array}{l}\text { Further development sus- } \\
\text { pended. Distortion fre- } \\
\text { quently noted (Pl. 1, fig. 4) }\end{array}$ \\
\hline $\begin{array}{l}\text { E4 } \\
\text { E } 63\end{array}$ & $\left.\begin{array}{l}15 \\
18\end{array}\right\}$ & $\begin{array}{l}30-40 \% \text { germination. } \\
\text { Majority of spores germinate } \\
\text { to the P.E.I. stage with no } \\
\text { further development }\end{array}$ & $\begin{array}{l}\text { Hyphae swollen, distorted and } \\
\text { frequently more branched } \\
\text { (Pl. 1, fig. 5). Slight increase } \\
\text { in growth }\end{array}$ \\
\hline $\begin{array}{l}\mathbf{X X 1 9} \\
\mathbf{Y} 27\end{array}$ & $\left.\begin{array}{l}24 \\
24\end{array}\right\}$ & $\begin{array}{l}\text { Germination completely } \\
\text { inhibited }\end{array}$ & $\begin{array}{l}\text { Further development inhibited. } \\
\text { Some formation of hyphal } \\
\text { protuberances at periphery } \\
\text { of zone (Pl. 2, fig. 9) }\end{array}$ \\
\hline
\end{tabular}

Of the four groups, that made up of the actinomycetes AA30 and AA53 exerted the least effect on the fungus. In the presence of the antibiotics of these organisms, only slight inhibition of germination and hyphal development was noted. A considerable diminution in degree of germination occurred with the actinomycetes AA 24 and AA 27. Although 10-20\% germination was noted, the development of the germ-tubes rarely progressed further than illustrated in Pl. I, fig. 3. This inhibition of development just after germination is referred to as post-emergence inhibition (P.E.I.). In the majority of instances further hyphal development was inhibited in the presence of these two actinomycetes. Some distortion of the more extensively developed mycelia was also noted (Pl. 1, fig. 4). The antibiotic effects of the actinomycetes E 4 and E 63 are distinguishable by inhibition at a post-emergence stage and by the characteristic distortion of the pre-developed hyphae. The typical stunted, swollen and 
branched appearance of Helminthosporium sativum is illustrated in Pl. 1, fig. 5 . The antibiotic effects of actinomycetes XX19 and Y 27 are characterized by the complete inhibition of germination and the formation of distinct hyphal protuberances on pre-developed hyphae within the antibiotic zone (Pl. 1, fig. 9).

The antibiotic effects of actinomycetes on spores and pre-developed hyphae of Helminthosporium sativum in acid, neutral and alkaline soils

A study of the antagonistic effects of the eight actinomycetes on spores and pre-developed hyphae in acid, neutral and alkaline soils was undertaken in view of earlier studies which demonstrated the controlling effects of these organisms on root-rot of wheat (Helminthosporium sativum) in these soils (Stevenson, 1956). The actinomycete + soil inoculum was again prepared with $\mathbf{2} \%$ soybean meal and the growth habits of the fungus were determined in sterile and non-sterile soils, with and without the addition of this material. The results of these investigations are summarized in Table 2.

The presence of soybean meal in the acid soil caused an adverse affect on the fungus. Although a high percentage germination was recorded for the sterile soil alone, the percentage germination in the sterile soil + soybean mixture was markedly less. No diminution in degree of germination was noted in the neutral and alkaline soils with soybean. This would suggest that the diminished degree of germination in the acid soil resulted from the combined effect of sterilization of the acid soil with the soybean meal. Further investigations demonstrated that total germination of Helminthosporium sativum spores resulted when the acid soil and soybean meal were sterilized separately before mixing. Inasmuch as the actinomycete + soil inocula used in these studies were prepared in sterilized soil + soybean mixtures, it is quite possible that the decreased germination and growth of $\boldsymbol{H}$. sativum in the actinomycete-inoculated acid soil was due to the toxic effects resulting from the combined sterilization rather than to antibiotic action. A study was made to determine the antibiotic activity of the actinomycetes in the acid soil when the inocula were prepared with a soil + soybean mixture in which the components were sterilized separately. In all cases $90-100 \%$ germination of the fungal spores resulted and there was no inhibition of further growth of the pre-developed hyphae. Since no antagonistic effects of the actinomycetes were noted, it would appear that these organisms cannot adapt themselves to the acid environment of this soil. Results of previous studies also suggested this (Stevenson, 1956).

A low percentage spore germination and the rapid destruction of the developed hyphae are characteristic effects on Helminthosporium sativum in nonsterile soils (Chinn, 1953). The addition of soybean meal to the non-sterile soil brings about a higher percentage germination and stimulates more extensive development of the hyphae prior to attack by the natural soil antagonists. Lysis and various forms of hyphal distortion were noted by $24 \mathrm{hr}$. and generally, after 3 days, only remnants of the vegetative growth remained.

For the most part, the antagonistic effects of the actinomycetes on germination and development of Helminthosporium sativum in the neutral and alkaline 
soils were identical with those observed on the fungus in the presence of the actinomycete antibiotics in vitro. In all cases there was a definite decrease in the development of the fungus in the presence of the actinomycetes, and the

'able 2. The effects of the actinomycetes on spores and pre-developed hyphae of Helminthosporium sativum after 3 days of exposure in acid, neutral and alkaline soils

\begin{tabular}{|c|c|c|c|c|}
\hline \multirow[b]{2}{*}{$\begin{array}{c}\text { Soil } \\
\text { treatments }\end{array}$} & \multicolumn{2}{|c|}{ Acid soil } & \multicolumn{2}{|c|}{ Neutral and alkaline soils } \\
\hline & $\begin{array}{c}\text { Spores } \\
\text { (\% germination and } \\
\text { degree of growth)* }\end{array}$ & $\begin{array}{l}\text { Pre-developed } \\
\text { hyphae }\end{array}$ & $\begin{array}{c}\text { Spores } \\
\text { (\% germination and } \\
\text { degree of growth })^{*}\end{array}$ & $\begin{array}{c}\text { Pre-developed } \\
\text { hyphae }\end{array}$ \\
\hline rile soil & $\begin{array}{l}90-100 \% \text { germina- } \\
\text { tion. }+++ \text { to } \\
++++\end{array}$ & $\begin{array}{l}\text { Healthy, extensive } \\
\text { growth }\end{array}$ & $\begin{array}{l}100 \% \text { germination. } \\
+++ \text { to }++++\end{array}$ & $\begin{array}{l}\text { Healthy, extensive } \\
\text { growth }\end{array}$ \\
\hline $\begin{array}{l}\text { rile soil }+ \\
\% \text { soybean } \\
\text { eal }\end{array}$ & $\begin{array}{c}\mathbf{4 0 - 5 0} \% \text { germina- } \\
\text { tion. }+ \text { to }++\end{array}$ & $\begin{array}{l}\text { Healthy, extensive } \\
\text { growth }\end{array}$ & $\begin{array}{l}100 \% \text { germination. } \\
+++ \text { to } t+++\end{array}$ & $\begin{array}{l}\text { Healthy, extensive } \\
\text { growth }\end{array}$ \\
\hline n-sterile soil & $\begin{array}{l}30 \% \text { germination. } \\
+ \text { to }++. \text { Germ } \\
\text { tubes lysed }\end{array}$ & $\begin{array}{l}\text { No further growth. } \\
\text { Majority of hyphac } \\
\text { lysed. Distortion } \\
\text { evident }\end{array}$ & $\begin{array}{c}10-30 \% \text { germina- } \\
\text { tion. }+ \text { to }++. \\
\text { Germ tubes lysed }\end{array}$ & $\begin{array}{l}\text { No further growth. } \\
\text { Majority of hyphae } \\
\text { lysed. Distortion } \\
\text { evident }\end{array}$ \\
\hline $\begin{array}{l}\text { n-sterile soil } \\
2 \% \text { soy- } \\
\text { :an meal }\end{array}$ & $\begin{array}{l}98 \% \text { germination. } \\
+++ \text { to }++++ \\
\text { Distortion and lysis } \\
\text { evident }\end{array}$ & $\begin{array}{l}\text { No further growth. } \\
\text { Distortion and lysis } \\
\text { evident }\end{array}$ & $\begin{array}{l}85 \text { to } 100 \% \text { germi- } \\
\text { nation. }++++ \text {. } \\
\text { Distortion and lysis } \\
\text { evident }\end{array}$ & $\begin{array}{l}\text { Majority of hyphae } \\
\text { completely lysed. } \\
\text { Distortion evident }\end{array}$ \\
\hline $\begin{array}{l}\text { tinomycetes } \\
\text { A30, AA53 } \dagger\end{array}$ & . & - & $\begin{array}{l}80-90 \% \text { germina- } \\
\text { tion. }+++ \text { to } \\
++++\end{array}$ & $\begin{array}{l}\text { Healthy, extensive } \\
\text { growth }\end{array}$ \\
\hline $\begin{array}{l}\text { inomycetes } \\
\text { A24, AA27 } \dagger\end{array}$ & $\begin{array}{c}25-40 \% \text { germina. } \\
\text { tion. }+ \text { to }++\end{array}$ & $\begin{array}{l}\text { No further } \\
\text { development }\end{array}$ & $\begin{array}{l}\text { 35-40 } \% \text { germina- } \\
\text { tion. +. Spores } \\
\text { germinated to } \\
\text { P.E.I. stage only }\end{array}$ & $\begin{array}{l}\text { No further growth. } \\
\text { Majority of hyphae } \\
\text { completely lysed } \\
\text { (Pl. 1, fig. 6). Some } \\
\text { distortion noted }\end{array}$ \\
\hline $\begin{array}{l}\text { inomycetes } \\
\mathbf{4}, \mathbf{E} 63 \dagger\end{array}$ & - & - & $\begin{array}{l}50 \% \text { germination. } \\
+ \text { to }++ \text {. P.E.1. } \\
\text { (Pl. 2, fig. } 7 \text { ) } \\
\text { Distortion of more } \\
\text { extensive mycelia }\end{array}$ & $\begin{array}{l}\text { No further growth. } \\
\text { Hyphae stunted, } \\
\text { swollen, with some } \\
\text { lysis at hyphal tips } \\
\text { (Pl. 2, fig. 8) }\end{array}$ \\
\hline $\begin{array}{l}\text { inomycetes } \\
\text { X19, Y27† }\end{array}$ & - & - & $\begin{array}{l}\text { 40-50 \% germina- } \\
\text { tion. +. No } \\
\text { further develop- } \\
\text { ment }\end{array}$ & $\begin{array}{l}\text { Slight increase in } \\
\text { growth. Formation } \\
\text { of hyphal pro- } \\
\text { tuberances (Pl. 2, } \\
\text { fig. } 9 \text { ) }\end{array}$ \\
\hline
\end{tabular}

Growth estimated as follows: $+=$ spore wall ruptured and germ-tube emerging; $++=$ development of

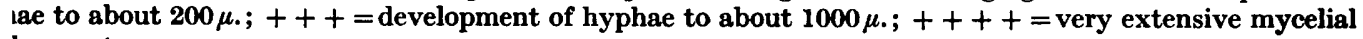
lopment.

Sterile soil $+2 \%$ soybean meal, inoculated with the actinomycete indicated.

degree of antagonism displayed by these organisms agreed with the degree of inhibition of the fungus in Petri plate culture. Some of the typical effects of the actinomycetes on $\boldsymbol{H}$. sativum in soil are illustrated in $\mathrm{Pl}$. 1, fig. 6, and Pl. 2, figs. 7, 8.

Although no lysis of Helminthosporium sativum was evident in the presence of the antibiotics in the in vitro studies, this effect was noted with some of the 
actinomycetes in soil. The actinomycetes E 4 and $\mathrm{E} 63$ frequently lysed the terminal portions of the developing hyphae (Pl. 2, fig. 8), but the complete lysis and destruction of the fungus was peculiar to actinomycetes AA 24 and AA 27 (Pl. 1, fig. 6). In the case of these latter organisms the lytic effect was generally evident by $24 \mathrm{hr}$., lysis of the fungus being completed in as little as 3 days. Further experiments established that although the antibiotics of actinomycetes AA 24 and AA 27 were incapable of exerting a lytic effect on the fungus by themselves, in combination with soil or soil extracts lysis did occur.

The foregoing experiments were repeated in soils to which no soybean meal had been added in the preparation of the actinomycete + soil inocula. In a previous report (Stevenson, 1956) it was found that antibiotics could not be detected by extraction techniques in inoculated unsupplemented soils. By means of the buried-slide technique it was shown that the effects of the actinomycetes on the fungus in these unsupplemented soils were, for the most part, identical with those outlined in Table 2. Some decrease in the degree of antibiosis was indicated by a higher percentage of unaffected spores and more extensive hyphal development.

The effect of actinomycin on spores and pre-developed hyphae of Helminthosporium sativur

In order further to substantiate the belief that the antagonistic effects noted in soil were due to antibiotics, use was made of the knowledge that the actinomycetes E4 and E63 were strains of Streptomyces antibioticus which produce the antibiotic actinomycin. The morphological changes induced by these actinomycetes in soil are very distinctive, and if the antibiotics produced by these organisms are the responsible agents, one would expect similar changes in Helminthosporium sativum in the presence of pure actinomycin.

The in vitro effects of actinomycin were determined by observing spores and pre-developed hyphae of the fungus in contact with a solution of actinomycin $(15 \mu \mathrm{g} . / \mathrm{ml}$.$) . Inhibition of spore germination, and swelling, distortion and$ excessive branching of the fungal hyphae identical with that reported for the actinomycetes E4 and E63 (Table 1) was again observed.

To study the effects in soil, known amounts of actinomycin $(3,5,10,15 \mu \mathrm{g} . / \mathrm{g}$. soil) were mixed with the sterile neutral soil before embedding slides containing spores and pre-developed hyphae. The typical antibiotic effects were again noted with all concentrations of actinomycin used. In view of these effects, it is significant that antibiotic could not be recovered in extracts of these actinomycin-containing soils. Inasmuch as the in vitro and soil effects of actinomycin were identical with the effects of actinomycetes E4 and E63 under the same conditions, it would appear that the inhibitory and antagonistic action of these organisms in soil is, in fact, due to actinomycin.

\section{DISCUSSION}

In a preliminary investigation of the antagonistic potential of a number of actinomycetes in soil (Stevenson, 1956) some evidence was produced which indicated that the competitive effects of these organisms were largely due to 
specific antibiotic action. Thus there was a correlation between the degree of control of root-rot of wheat due to Helminthosporium sativum by a number of actinomycetes in pot experiments and the degree of antibiotic action shown by in vitro assay. But no relationship was detected between the effects of these actinomycetes in diminishing the disease and their ability to produce antibiotics in soil as assessed by soil-extraction techniques. In this present study, a direct observation technique was used to determine the effects of the actinomycete antibiotics of Helminthosporium sativum. Three additional lines of evidence support the theory of specific antibiotic action in soil. This new evidence depends on: (1) on a correlation between the degree of inhibition of spore germination by the eight actinomycetes in soil and in vitro; $(2)$ the close resemblance between the specific effects produced by these actinomycetes on the hyphae of $\boldsymbol{H}$. sativum in soil and those produced by the actinomycete antibiotics in vitro; (3) the fact that the very characteristic effects caused by Streptomyces antibioticus resemble exactly those brought about in soil and in vitro by actinomycin which is produced by this actinomycete. In addition, antibiotic activity in actinomycete-inoculated unsupplemented soils has also been demonstrated.

Although most of these studies were carried out in sterile soils, it is significant that the antibiotic effects of the actinomycetes observed on Helminthosporium sativum are very similar to those detected when this fungus is placed in natural soils. In view of the much higher concentration of antagonistic organisms in such soils, a more rapid rate of destruction is to be expected. Nevertheless, such typical antibiotic effects as inhibition of germination, hyphal distortion, and lysis, are readily recognizable in these non-sterile soils.

The frequent failure to extract detectable quantities of antibiotics from natural soils does not preclude the presence and activity of these substances in them. It is possible that antibiotic production occurs only in restricted loci, such as, in the vicinity of local concentrations of suitable carbon sources. Under such conditions, a localized antibiotic effect might well be exerted on susceptible organisms even though the overall concentration of antibiotic material is too small to be detected by extraction. For this reason it is felt that direct observation techniques are necessary for the detection of antibiotic activity in such physically restricted environments.

The author wishes to thank Dr G. H. Thornton, F.R.S., for his advice during the course of the work. This paper is contribution no. 415 from the Bacteriology Division, Science Service, Department of Agriculture, Ottawa, Canada.

\section{REFERENCES}

Blair, I. D. (1943). Behaviour of the fungus Rhizoctonia solani Kühn in the soil. Ann. appl. Biol. 30, 118.

Blair, I. D. (1945). Techniques for soil fungus studies. N.Z. J. Sci. Tech. A, 26, 258.

Brian, P. W., Curtis, P. J. \& Hemming, H. G. (1946). A substance causing abnormal development of fungal hyphae produced by Penicillium janczeroskii Zal. Trans. Brit. mycol. Soc. 29, 173. 
Chins, S. H. F. (1953). A slide technique for the study of fungi and actinomycetes in soil with special reference to Helminthosporium sativum. Canad. J. Bot. 31, 718.

Christensen, J. J. \& Davies, F. R. (1940). Variation in Helminthosporium sativum produced by Bacillus mesentericus. Phytopathology, 30, 1017.

DobBs, C. G. \& Hinson, W. H. (1953). A widespread fungistasis in soils. Nature, Lond. 172, 197.

Gottlieb, D. \& Siminoff, P. (1952). The production and role of antibiotics in soil. II. Chloromycetin. Phytopathology, 42, 91.

Gregory, K. F., Allen, O. N., Riker, A. J. \& Peterson, W. H. (1952). Antibiotics as agents for the control of certain damping-off fungi. Amer. J. Bot. 6, 405.

Grossbard, E. (1952). Antibiotic production by fungi on organic manures and in soil. J. gen. Microbiol. 6, 295.

Jefferys, E. G. \& Hemming, H. G. (1953). Fungistasis in soils. Nature, Lond. 172, 872.

Lachance, R. O. (1951). Antagonisme des Microorganismes du Sol Envers le Colletotrichum Linicola, Agent de l'Anthracnose du Lin. Canad. J. Bot. 29, 438.

LEgGe, B. J. (1952). Use of glass fibre material in soil mycology. Nature, Lond. 169, 759.

Mitchell, R. B., Hooton, D. R. \& Clark, F. E. (1941). Soil bacteriological studies on the control of the Phymatotrichum. Root-rot of cotton. J. Agric. Res. 63, 535.

Reirly, H. C., Schatz, A. \& Waksman, S. A. (1945). Antifungal properties of some antibiotic substances. J. Bact. 49, 585.

Rombouts, J. E. (1953). Abnormal development of fungi induced by antibiotics. Proc. VI Congr. int. Microbiol. 5, 205.

Stevenson, I. L. (1956). Antibiotic activity of actinomycetes in soil and their controlling effects on root-rot of wheat. J. gen. Microbiol. 14, 440.

Tvert, M. (1953). Control of seed-borne diseases of cereals by Chaetomium cochlioides, Pall. Proc. VI Congr. int. Microbiol. 6, 350.

\section{EXPLANATION OF PLATES}

\section{Plate 1}

Fig. 1. Plate technique used for assessing the antibiotic effects of actinomycetes on spores of Helminthosporium sativum.

Fig. 2. Plate technique used for assessing the antibiotic effects of actinomycetes on predeveloped hyphae of $\boldsymbol{H}$. sativum.

Fig. 3. Spore of $H$. sativum showing post emergence inhibition in the presence of the antibiotic of actinomycete AA 24 ( $\times$ 343).

Fig. 4. Hyphal distortion in the presence of the antibiotic of actinomycete $A A 27(\times 77)$.

Fig. 5. Swollen, distorted and branched appearance of $H$. sativum in the presence of the antibiotics of actinomycetes $\mathrm{E} 4$ and $\mathrm{E} 63$ ( $\times 343)$.

Fig. 6. Lysis of pre-developed hyphae of $H$. sativum in soil inoculated with actinomycete AA 24 ( $\times$ 343).

\section{Plate 2}

Fig. 7. Post-emergence inhibition in soil inoculated with actinomycete $\mathbf{E} 63(\times 392)$.

Fig. 8. Distortion and lysis of $\boldsymbol{H}$. sativum in soil inoculated with actinomycete $\mathbf{E} 4(\times 392)$.

Fig. 9. Typical hyphal protuberances formed by $H$. sativum in the presence of the actinomycete $\mathrm{XX} 19$ in soil; similar to the distortion noted in the in vitro studies $(\times 88)$. 
Journal of General Microbiology, Vol. 15, No. 2
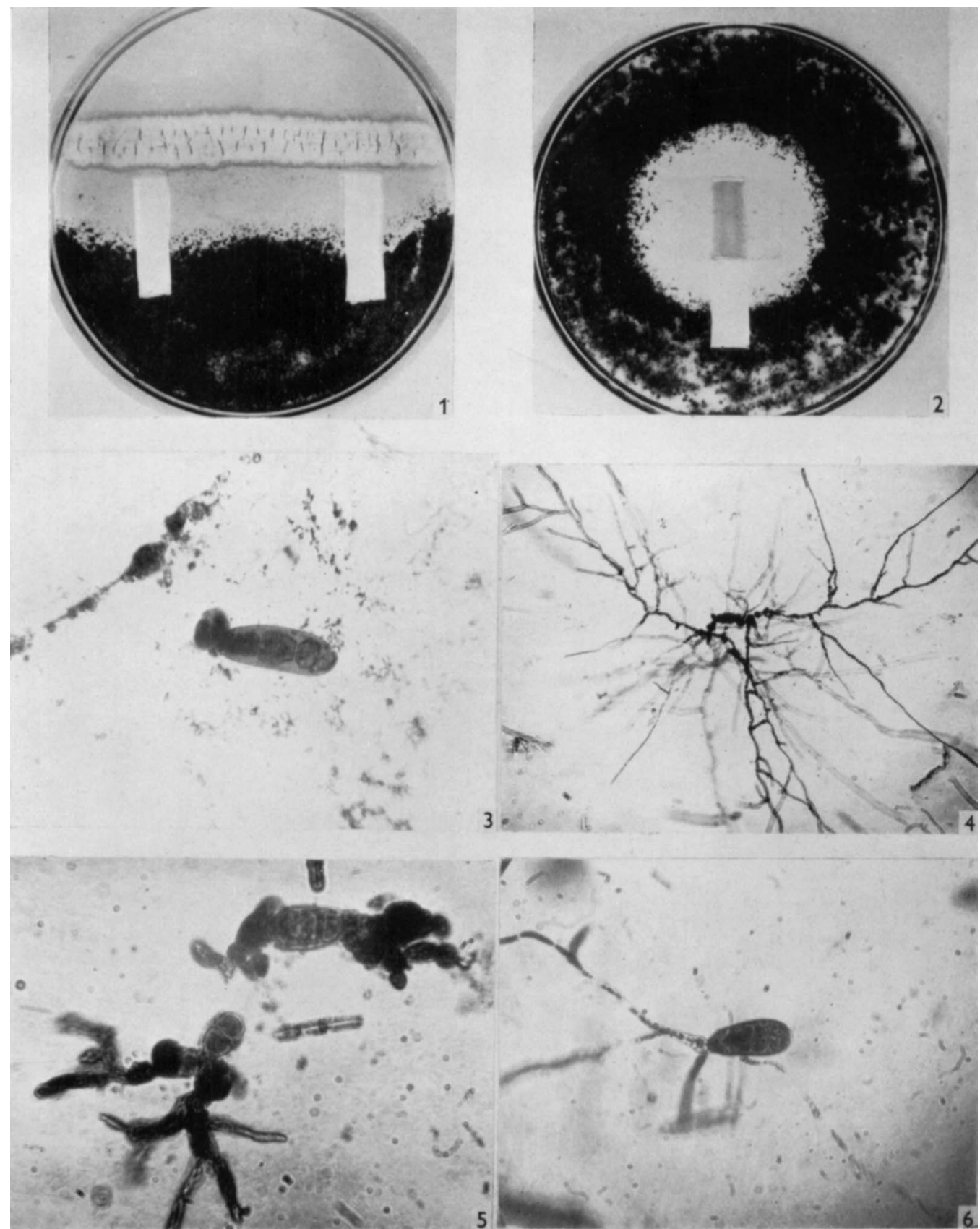

I. L, Stevenson-Antibiotic activity of actinomycetes in soil. Plate 1

(Facing $p .380$ ) 
Journal of General Microbiology, Vol. 15, No. 2

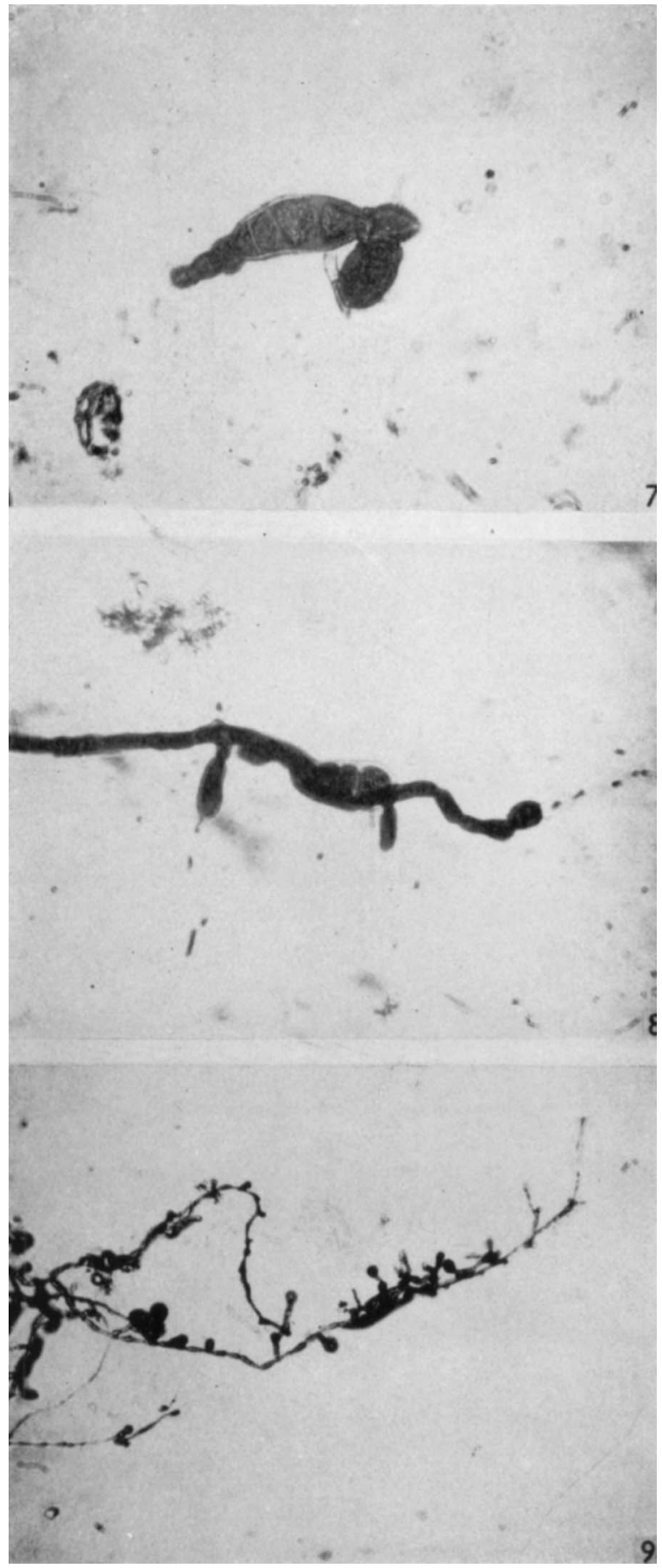

I. L. Stevenson-Antibiotic activity of actinomycetes in soil. Plate: 2 